\title{
The Biological Implications of the Transition to Agriculture in Ukraine: A Study of Enamel Hypoplasias
}

\author{
Jordan K. Karsten ${ }^{1 *}$, Sarah E. Heins ${ }^{1}$, Gwyn D. Madden², Mykhailo P. Sokhatskyi ${ }^{3}$ \\ ${ }_{1}^{1}$ Department of Religious Studies and Anthropology, University of Wisconsin Oshkosh, Oshkosh, Wisconsin, 54901 \\ 2Department of Anthropology, Grand Valley State University, Allendale, Michigan, 49401 \\ ${ }^{3}$ Borschiv Regional Museum, Ministry of Culture and Arts of Ukraine, Borschiv, Ukraine
}

Keywords: dental pathology, hunter-fisher-gatherers, Mesolithic, Neolithic

ABSTRACT The Tripolye were the first archaeological culture in Ukraine to cultivate domesticated cereals, practice animal husbandry, and establish large settlements with high population densities. This cultural adaptation was much different than that of mobile hunter-fisher-gatherers of the Ukrainian Mesolithic/Neolithic, and likely resulted in different outcomes for human health. This study compares the rates of enamel hypoplasias in a Tripolye skeletal population with that of Mesolithic/Neolithic hunter-fisher-gatherers. A recently excavated sample of dentitions representing a minimum of 35 individuals from Verteba Cave was examined macroscopically for hypoplasias and was compared statistically to published rates

The Tripolye were the first archaeological culture in Ukraine to possess the full Neolithic package of domesticated cultigens, livestock, and pottery (Korvin-Piotrovskiy, 2008). Compared to earlier Ukrainian populations, the Tripolye interacted with their environment in a radically different way through their use of an agropastoral subsistence system and settlement in more sedentary villages with higher population densities. These changes likely had implications for the health of prehistoric humans living in the area of modern Ukraine. The goal of this study is to assess the relative success of the Tripolye cultural adaptation from a biocultural perspective. Specifically, we use enamel hypoplasias to document the level of physiological stress experienced by the Tripolye and compare this to earlier Ukrainian Mesolithic and Neolithic hunter-fisher-gatherer populations.

Enamel hypoplasias are areas of abnormally thin enamel found on the crowns of teeth (Goodman and Rose, 1991). Enamel hypoplasias can take the form of horizontal linear grooves, pits, or large areas of missing enamel (Goodman and Rose, 1990). These lesions form during the years of enamel development, from infancy to late childhood, and result from insufficient enamel production due to the disruption of enamel producing cells called ameloblasts (Hillson, 1996). Ameloblast disruption can be caused by a variety of factors, including malnutrition, infection, localized trauma, and congenital defects (Goodman and Rose, 1991). However, the rates of linear enamel hypoplasias for hunter-fisher-gatherers. The Tripolye from Verteba Cave were found to have at least one enamel hypoplasia on $18.18 \%$ of teeth, while the hunter-fisher-gatherers have hypoplastic lesions on $1.88 \%$ of teeth. When examined at the individual level, $48.57 \%$ of the Tripolye were found to have at least one hypoplasia, as compared to $12.77 \%$ of the hunter-fisher-gatherer individuals. The results indicate that the agropastoral Tripolye experienced significantly more systemic stress than the hunter-fisher-gatherers. The higher stress likely relates to dietary and behavioral variables associated with the Tripolye's agropastoral economy, including heavy reliance on cereals as weaning foods and sanitary problems linked to sedentism.

caused by trauma and hereditary conditions are estimated to be extremely low, and therefore most of these lesions are believed to reflect physiological stress resulting from malnutrition, infection, or the synergistic interaction of both (Goodman et al., 1980; Winter and Brook, 1975). This notion has been reinforced by studies of living populations, which have found a positive relationship between the prevalence of enamel hypoplasias and the degree of malnutrition and disease (Cutress and Suckling, 1982; Goodman et al., 1987). As a nonspecific indicator of physiological stress, linear enamel hypoplasias are well suited to monitor the general biological well-being of prehistoric populations.

\section{BIOARCHAEOLOGICAL STUDIES OF THE TRANSITION TO AGRICULTURE}

Previous bioarchaeological studies have used enamel hypoplasias to examine the impact of the transition to agriculture on the health of ancient human populations. Studies from regions around the globe, including North America's Ohio River Valley, Illinois, India, China, Egypt, the Andes,

\section{Correspondence to:}

Jordan K. Karsten, Department of Religious Studies and Anthropology, UW Oshkosh, 800 Algoma Boule-

vard, Oshkosh, WI 54901

Phone: (920) 424-7307

Fax: (920) 424-0882

Email: karstenj@uwosh.edu 
and Mesoamerica, have documented increases in the prevalence of enamel hypoplasias following the adoption of agriculture (Cassidy, 1984; Perzigian et al., 1984; Goodman et al., 1984; Marquez-Morfin and Storey, 2007; Alfonso et al., 2007; Lukacs et al., 2001; Pechenkina et al., 2002). For example, in their study of burials from the multicomponent site of Dickson Mounds, Illinois, Goodman et al. (1984) found the rate of enamel hypoplasias to significantly increase following the transition to agriculture. The cumulative impact of these studies has led many researchers to conclude that the transition to agriculture was detrimental to human health (Larsen, 1995; 2006; Cohen and Armelagos, 1984; Cohen and Crane-Kramer, 2007; Armelagos et al., 1991). However, it is important to point out that some studies have found the rate of enamel hypoplasias to decline or remain unchanged following the agricultural transition (Hodges, 1987; Temple, 2010; Danforth et al., 2007). For instance, Temple (2010) found a decline in the prevalence of enamel hypoplasias following the transition to agriculture in his comparison of Jomon hunter-gatherers and Yayoi agriculturalists from Japan. Other studies have found patterns that are difficult to interpret. Starling and Stock (2007) observed an initial increase in the rate of enamel hypoplasias following the adoption of agriculture in Egypt and Nubia. Interestingly, this transitional stress appeared to be short lived, as the rate of hypoplastic lesions gradually declined through time. The variable results of these studies demonstrate that our understanding of the health consequences of the transition to agriculture remains incomplete.

Compared to the rest of the globe, very few studies have focused on the health consequences of the transition to agriculture in prehistoric Europe (Meiklejohn and Zvelebil, 1991). Papathanasiou (2005; Papathanasiou et al., 2000) documented enamel hypoplasias in Neolithic skeletons from Greece, and concluded the population experienced relatively low levels of systemic stress. Due to a lack of Mesolithic burials in the area, the rates of enamel hypoplasias among agriculturalists could not be compared to hunter-gatherers. Bennike and Alexandersen (2007) studied the biological impacts of the transition to agriculture in Scandinavia, and found the rates of enamel hypoplasias to decline following the adoption of an agricultural economy and then increase over time.

This study aims to address the general scarcity of European data on the health consequences of the transition to agriculture by analyzing relevant skeletal populations from Ukraine. Based on the results of previous bioarchaeological studies, we seek to test the hypothesis that the transition to agriculture was detrimental to the health of prehistoric populations living in Ukraine.

\section{BIOCULTURAL CONTEXT}

\section{Ukrainian Mesolithic and Neolithic Populations}

In Ukrainian archaeological terminology "Neolithic" is used to mark the appearance of pottery rather than the transition to agriculture as it is elsewhere in Europe (Jacobs, 1993). In fact, at many Ukrainian Neolithic sites, the presence of pottery may be limited to a few sherds, while at others pottery is not present (Lillie, 1996). The Ukrainian Neolithic sites show continuity with earlier Mesolithic sites in material culture, burial practices, and subsistence systems, and therefore, the Mesolithic and Neolithic sites will be discussed together here.

Much of what is known about the Mesolithic/ Neolithic period in Ukraine comes from the mariupol -type cemeteries excavated in the Dnieper Rapids region (Zvelebil and Lillie, 2000; Lillie, 1996; Jacobs, 1993). Stable isotope studies on the skeletal remains suggest that these populations consumed diets rich in fish and terrestrial animals (Lillie and Richards, 2000; Lillie and Jacobs, 2006; Lillie et al., 2011; Lillie and Budd, 2011). The consumption of a diet rich in protein and low in carbohydrates is further supported by analysis of dental pathology in these skeletal samples, which have been found to be universally free of dental caries (Lillie, 1996). The ephemeral nature of the Mesolithic/Neolithic settlements in the area, a lack of domesticated cultigens in the archaeological record, and the appearance of only a limited number of domesticated fauna at the end of the Neolithic have led researchers to conclude that these populations were fairly mobile hunter-fisher-gatherers (Lillie, 1996; Zvelebil and Lillie, 2000).

In his examination of dental pathology in the Mesolithic/Neolithic populations from the Dnieper Rapids region, Lillie (1996) documents and interprets the occurrence of enamel hypoplasias. He found enamel hypoplasias throughout the sample, although at a relatively low prevalence. Specifically, Lillie observed at least one enamel hypoplasia on $16.66 \%$ of Mesolithic individuals and $11.42 \%$ of Neolithic individuals for a pooled rate of $12.77 \%$. When examined by teeth, Lillie found $1.22 \%$ of Mesolithic teeth and $2.25 \%$ of Neolithic teeth to have one or more hypoplasias. According to Lillie, the rates of enamel hypoplasias indicate suboptimal levels of subadult health during the Mesolithic/Neolithic period, but the low 
frequencies do not indicate severe systemic stress, suggesting a generally healthy existence for the Mesolithic/Neolithic Ukrainian hunter-fisher-gatherers.

\section{Tripolye}

The Tripolye were an Eneolithic people that existed between $4800-2900 \mathrm{cal}$ BC on territory that now corresponds to the modern nations of Ukraine, Moldova, and Romania (Zbenovich, 1996; Rassamakin, 2012). In Ukraine, the Czech Republic, and Slovakia, the Eneolithic is defined as beginning with the appearance of copper artifacts and the onset of copper metallurgy and ends with the start of the Bronze Age (Milisauskas, 2011). The Tripolye culture occupied an area stretching from the Carpathian piedmont in the west, to the Dnieper River in the east, and extended as far south as the Black Sea and as far north as Kiev (Videiko, 2004). The term Tripolye is derived from the name of the Ukrainian village near the first discovery of Tripolye material culture in 1896 by V. Khvoika (Nikitin et al., 2010). Tripolye cultural remains were independently discovered in Romania, and are known there as Cucuteni (Lillie, 2008). Consequently, publications referring to the Tripolye culture also use the terms Tripolye-Cucuteni or $\mathrm{Cu}$ cuteni-Tripolye to recognize their unity (e.g. Zvelebil and Dolukhanov, 1991).

Detailed relative and absolute chronologies have been developed that divide the existence of the Tripolye into a number of different phases, including the Tripolye A (4900-4300 calBC), Tripolye BI (43004100 calBC), Tripolye BII (4100-3600 calBC), Tripolye CI (3600-3200 calBC,) and Tripolye CII (3400-2750 calBC) (Nikitin et al., 2010; Videiko, 2004). These different phases are associated changes in pottery manufacture and decoration (Ryzhov, 2012).

Paleobotanical evidence indicates that the Tripolye cultivated a wide variety of domesticated crops including the hulled wheat types of emmer, einkorn, and spelt, hulled and non-hulled barley, peas, bitter vetch, and lentils (Pashkevych, 2008). The frequent recovery of hulled wheat plants from Tripolye sites supports the notion that these crops were important components of the Tripolye diet (Zbenovich, 1996). These cereals may have been consumed as porridges, as indicated by crushed hulled wheat grains found inside a pot at the site of Maydanetske (Pashkevych, 2008).

Zooarchaeological evidence indicates that Tripolye populations also practiced animal husbandry. Tripolye livestock herds included cattle, pigs, sheep, and goats (Markova, 2008; Zhuralev, 2008). Although the relative importance of each domesticated animal species varies between sites, cattle are often dominant (Korvin-Piotrovskiy, 2012). At the sites of Traian -Doalul Viei and Tirpesti I cattle make up over $45 \%$ of the faunal osteological material (Ellis, 1984; Marinescu-Balcu, 1981). However, at the site of Mayaki, sheep and goats make up $64 \%$ of the faunal assemblage, while at Luka-Vrublevetska, pigs are the most common species (Ellis, 1984).

In addition to agropastoral activites, Tripolye populations engaged in hunting and gathering a wide range of wild species (Lillie, 2008). Gathered foods like wild grapes, cornelian cherries, plums, and pears have been identified at Tripolye sites (Pashkevych, 2004), and identification of animal species such as roe deer, red deer, wild pigs, aurochs, and catfish demonstrate that hunting and fishing were also practiced (Korvin-Piotrovskiy, 2012). For some Tripolye populations it is likely that hunting greatly contributed to the diet, as wild animals comprise over half the zooarchaeological material at the CI period site of Kolomyishchina (Lillie, 2008).

Tripolye settlements vary in size, ranging from small seasonal sites to large permanent settlements (Chapman, 2010). Villages are located near permanent sources of water and are usually on the edge of the first river terrace or on promontories of steep river banks (Zbenovich, 1996). Some settlements dated to the middle period (B Period) of the Tripolye culture are found to be fortified with ramparts or surrounded by ditches (Passek, 1961; Markevich, 1981). Early (A Period) Tripolye hamlets and villages are relatively small and vary in aerial extent from 0.5-6 hectares, usually containing fewer than 15 residential structures (Zbenovich, 1996). In the later periods (B-C Periods), many villages reached $20-40$ hectares in size and were composed of an average of 200 dwellings (Zbenovich, 1996). Some later settlements were extremely large, such as Talyanki, which was 450 hectares in area (Kruts, 1989). These "megasites" were the largest in Europe at the time (Kruts, 2012) and were occupied year-round for a period up to 50 years, representing relatively sedentary settlement practices (Korvin-Piotrovskiy et al., 2012).

The Tripolye were a densely settled group, with the population density of the Dniester area estimated at 12 individuals per square kilometer, making it one of the most densely settled areas in Europe (KorvinPiotrovskiy, 2012). Likewise, the site of Talyanki has been estimated to contain over 2,000 residential structures and have a population of 14,000 individuals (Kruts, 2012), rivaling major prehistoric urban centers. 


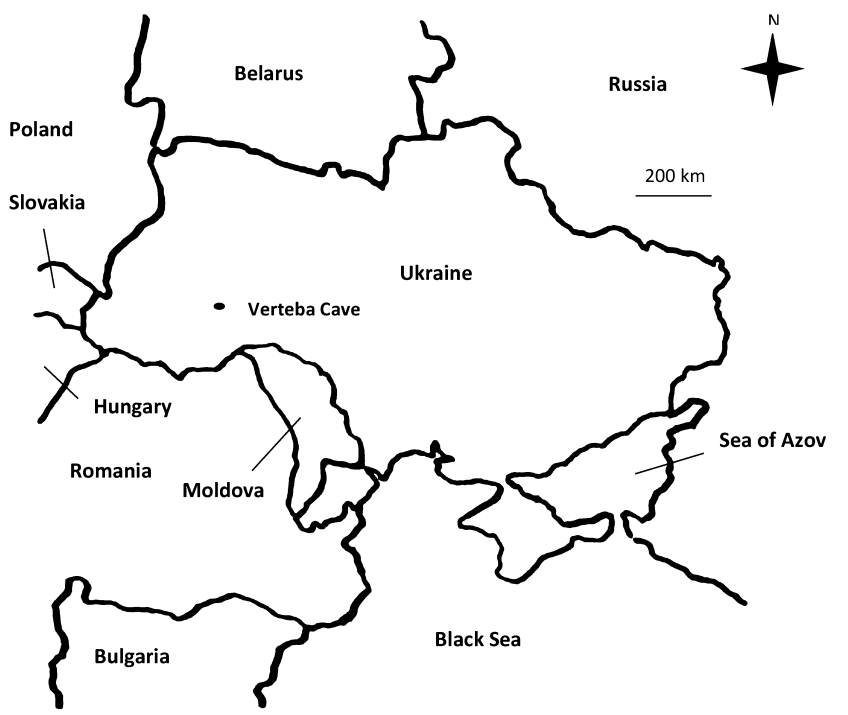

Fig. 1. Location of Verteba Cave.

\section{MATERIALS AND METHODS}

The dental sample used to test our hypothesis include all known dentitions and loose teeth excavated from Verteba Cave, a mortuary site located outside the modern village of Bilche Zolote, Ternopil Oblast, Ukraine (Figure 1). The human remains found in the cave have been attributed to the Eneolithic Tripolye culture based on associated pottery, lithics, and ceramic figurines. Radiocarbon dating of the human bone, faunal remains, charcoal, and pottery from Verteba Cave place the site's use between 3800-2600 calBC (Nikitin et al., 2010). Analysis of pottery places the use of the cave during the BII, CI, and CII periods of the Tripolye relative chronology. Very few human remains attributable to the Tripolye are known prior to the CII period, making the skeletons from Verteba Cave extremely valuable in terms of studying the biology and mortuary customs of this population.

The sample was collected over the course of two periods of excavation. The most recent excavations took place over the field seasons of 2008 and 2012, and were conducted by the authors. These excavations yielded a minimum number of 36 individuals recovered as comingled secondary burials, mixed with pottery, ceramic figurines, stone and bone tools, and faunal remains. This material is housed on site by the Borschiv Regional Museum. In addition to the specimens collected during the two recent field seasons, the remains of a minimum of 24 individuals were examined that were excavated from Verteba Cave during the late 19th century by Polish archaeologists. These human remains are curated at the Museum of Archaeology in Krakow, Poland. Only crania and mandibles are present in the Krakow museum collection. Although detailed field notes are not available regarding the excavation of the material from the 19th century, their association with diagnostic Tripolye pottery supports the pooling of this sample with the more recently excavated material.

A pooled sample of 231 permanent teeth from a minimum of 35 individuals was examined for enamel hypoplasias (Table 1). A total of 121 permanent teeth representing a minimum of nineteen individuals were collected during the two most recent field seasons. Of the 121 teeth, thirteen are not associated with a maxilla or mandible. A total of 110 permanent teeth representing a minimum of 16 individuals were available for study in the Krakow collection. Twentyone of the teeth in the Krakow collection were not associated with a mandible or maxilla.

Due to the comingled nature of the burials, sex and age were assigned to individual crania and mandibles. Ages-at-death were determined using dental development, dental attrition, and cranial suture closure (Buikstra and Ubelaker, 1994; Lovejoy, 1985; Meindl and Lovejoy, 1985). Due to the fact that more accurate aging methods could not be employed since no associated os coxae were available, individuals were segregated into age categories of "subadult" and "adult". Sex was determined for adults using the standard morphological characteristics (Buikstra and Ubelaker, 1994; Walker, 2008).

All of the teeth were examined for the presence or absence of enamel hypoplasias. The lesions were recorded following the method described by Lukacs (1989; 1992) and Temple (2010), with teeth examined macroscopically under diffuse lighting with a second light source positioned at an oblique angle to the specimen. A handheld 10x magnifier was used in some cases to help identify defects. This technique allows for optimal perikymata detection. To avoid confusing enamel hypoplasias with normal perikymata, the spacing of adjacent perikymata were compared to potential defects (Skinner et al., 1995). Each tooth examined was scored as either having an enamel hypoplasia present or absent. For teeth with hypoplastic lesions, the number of enamel hypoplasias present was recorded. The number of individuals displaying at least one enamel hypoplasia was also recorded. In Verteba Cave, some maxillae and mandibles representing single individuals are associated with one another, while others are isolated. When associated, upper and lower jaws are counted as single individuals. In cases where isolated mandibles and maxillae were not definitively associated with their occluding jaw, the isolated element is treated as an individual. This potentially overestimates 
TABLE 1. Composition of sample by tooth type

\begin{tabular}{cccc}
\hline Tooth Type & Teeth & Tooth Type & Teeth \\
\hline Maxillary & & Mandibular & \\
Incisors & 17 & Incisors & 2 \\
Canines & 19 & Canines & 5 \\
Premolars & 43 & Premolars & 18 \\
Molars & 92 & Molars & 35 \\
& & & \\
Total Maxillary & 171 & Total Mandibular & 60 \\
& & & \\
\hline
\end{tabular}

TABLE 2. Enamel hypoplasia frequencies

\begin{tabular}{ccc}
\hline Sample & $\begin{array}{c}\text { Ratio of Teeth With At Least 1 Hy- } \\
\text { poplasia To Total Teeth Observed }\end{array}$ & $\begin{array}{c}\text { Ratio of Individuals With At Least } \\
\text { 1 Hypoplasia To Total Individuals } \\
\text { Observed }\end{array}$ \\
\hline $\begin{array}{c}\text { Verteba Cave Tripolye } \\
\text { Agriculturalists }\end{array}$ & $42 / 231$ & $17 / 35$ \\
$\begin{array}{c}\text { Mesolithic/Neolithic Hunter- } \\
\text { Fisher- Gatherers (Lillie, 1996) }\end{array}$ & $43 / 2284$ & $18 / 141$ \\
\hline
\end{tabular}

the number of individuals present in the sample, however, we believe it provides the most appropriate way to organize the available dental material. Loose teeth were not included in the individual count. Wear in the Verteba Cave sample was not severe and no tooth crowns had lost over one-third of their height to macrowear. Therefore, wear did not bias the identification of enamel hypoplasias in the sample.

The data on enamel hypoplasias among the Tripolye from Verteba Cave will be presented in two ways following Lillie (1996) to allow for statistical comparison with Ukrainian hunter-fisher-gatherer populations. The first is the tooth count method, where the number of teeth with at least one enamel hypoplasia is presented as a ratio to the total number of observable teeth. This method has the advantage of using a large sample size, which increases the power of statistical analysis (Lukacs, 1992). One drawback to the tooth count method is that it may overestimate stress. Single stress events are recorded on all teeth developing at the time of a physiological insult. Therefore, the tooth count method can overestimate the stress experienced by a population by treating all of the defects resulting from one stress episode as representing independent stress events. The second way enamel hypoplasia data will be presented is using the individual count method, where each dentition representing a single individual is scored as either having one or more enamel hypoplasias or as lacking hypoplasias altogether. The individual count method has the advantage of focusing on the individual, the primary unity upon which selection acts (Lukacs, 1992). One disadvantage of using the individual count method with prehistoric skeletal samples is that it often results in small sample sizes and reduces the power of statistical analysis (Lukacs, 1992). The relative frequencies of enamel hypoplasias for agriculturalists and hunter-fishergatherers are compared using $\chi^{2}$-tests $(\alpha=0.05)$.

A recent study by Hassett (2012) has demonstrated that, as compared to microscopic methods, examination of teeth with the naked-eye provides a minimum estimate of the number of hypoplastic defects. As microscopic analysis was not possible with the sample from Verteba Cave, the current data will be regarded as a conservative approach to quantifying systemic stress among prehistoric populations from Ukraine.

\section{RESULTS}

The Eneolithic Tripolye agriculturalists from Verteba Cave have significantly more enamel hypoplasias than the Mesolithic/Neolithic hunter-fishergatherers when examined using both the tooth count $(x 2=168.993, p<0.001)$ and individual count methods $\left(x^{2}=20.58, p<0.001\right)($ Table 2$)$. The Tripolye have at least one enamel hypoplasia on $18.18 \%$ of the teeth 
examined. In comparison, the hunter-fisher-gatherers have enamel hypoplasias on $1.88 \%$ of teeth. Among the Tripolye, $48.57 \%$ of observable individuals had at least one enamel hypoplasia, as compared to $12.77 \%$ of individuals in the hunter-fisher-gatherer sample.

The rate of enamel hypoplasias in Tripolye subadult (2/4 individuals) and adult dentitions (15/31 individuals) was similar. Hypoplasias occurred at the highest prevalence on canines $(45.83 \%)$, followed by incisors (33.33\%), premolars (19.67\%), and molars (10.24\%). This pattern of prevalence by tooth type is not unexpected based on the known differences in susceptibility (Goodman and Rose, 1990).

\section{DISCUSSION}

Analysis of enamel hypoplasias indicates that the agropastoral Tripolye experienced significantly more systemic physiological stress than earlier hunterfisher-gatherers. This suggests that the introduction of agriculture and its associated sedentary lifestyle had negative consequences for human health in prehistoric Ukraine. The results lead us to accept our hypothesis that the transition to agriculture was detrimental to health in our study area. However, due to the small sample size of dentitions from Verteba Cave, the results must remain preliminary. Excavations are ongoing at the site with the aim of expanding the sample size.

Enamel hypoplasias form during the period of enamel development and leave an indelible record of systemic stress that occurred during infancy and childhood (Larsen, 1997). Weanling stress, diarrheal diseases, malnutrition, and infection are all commonly implicated as causative agents in the formation of enamel hypoplasias (Goodman and Rose, 1990). Nutritional stress engendered by an agricultural diet may be a contributing factor to the higher rates of systemic stress observed among the Tripolye. Cereals were a major component of the Tripolye diet (Zbenovich, 1996), and may have been a primary weaning food in the form of porridges (Pashkevych, 2008). However, cereals lack essential amino acids, such as lysine, are a generally poor source of protein, and are deficient in vital minerals such as iron (Baynes and Bothwell, 1990; Abdel-aal and Hacl, 2002). High reliance on cereals, especially as weaning foods, and reduced dietary variability as a consequence of an agricultural economy could have resulted in malnutrition and contributed to the relatively high systemic stress observed in the Tripolye skeletal sample.

The practice of animal husbandry by the Tripolye makes it likely that they were consuming at least some protein- and nutrient-rich animal products and meat. However, Mesolithic/Neolithic groups from Ukraine had diets highly focused on the meat of terrestrial animals and fish, with a lesser focus on vegetation (Lillie, 1996; Lillie and Richards, 2000). Such a diet would be nutritionally superior to one focused on domesticated cereals, and likely contributed to the lower incidence of systemic stress observed among Mesolithic/Neolithic peoples in this study.

In addition to dietary factors, changes in population density and behavior associated with the adoption of agriculture likely altered the disease ecology of the Tripolye farmers as compared to the Mesolithic/Neolithic hunter-fisher-gatherers. Both the farmers and the hunter-fisher-gatherers would have been affected by infections of enteric bacteria such as Salmonella, E. coli, and Staphylococcus (Cockburn, 1971). Likewise, both groups would have experienced some zoonotic diseases transmitted through insect bites and the consumption of contaminated meat (Armelagos, 1990). However, as compared to the mobile Mesolithic/Neolithic hunter-fishergatherers who lived in small bands, the settlement of the Tripolye in sedentary villages with high population densities would have resulted in a significantly different disease ecology. The densely settled Dniester region and megasites such as Talyanki would have easily met the threshold for the maintenance of contagious crowd diseases such as measles, influenza, smallpox, and mumps (Armelagos, 1990). Additionally, densely settled sedentary populations, such as the Tripolye, would have quickly contaminated their environments with their own waste, leading to sanitary health hazards (Larsen, 1995). This environmental contamination can lead to diarrheal diseases and parasitic infections, which can result in malnutrition through a reduction in the efficiency of nutrient absorption and the loss of nutrients to parasitic activity (Walker, 1986). Diarrheal disease can have especially harmful effects on subadults (Walker et al., 2009), and were likely a contributing factor to the elevated systemic stress documented in the Tripolye agriculturalists. By contrast, the low population density of Mesolithic/Neolithic hunter-fisher-gatherers would have precluded the existence of contagious crowd diseases, and their mobile lifestyle would have prevented infections resulting from environmental contamination (Armelagos, 1990).

The Tripolye would have also experienced close contact with domesticated animals via the practice of pastoralism, which would have significantly altered their disease ecology as compared to earlier hunter- 
fisher-gatherers. Close contact with domesticated animals would have exposed the Tripolye to novel zoonotic diseases and infections including tapeworm parasites, viruses, rabies, and tuberculosis (Armelagos, 1990). One specific cultural practice may have made the risk of zoonotic diseases especially severe for the Tripolye. Although the reconstruction of houses has been controversial in Tripolye archaeology, it seems that they constructed two-story structures where the ground floor served as a stable for animals and the top floor was used for human habitation (Korvin-Piotrovskiy et al., 2012). The ground floor of these structures was constructed using timber to build a log cabin-like frame that would have provided a sturdy structure to contain animals, unlike wattle-and-daub walls, which are easily destroyed by pigs (Korvin-Piotrovskiy et al., 2012). By keeping farm animals in their homes, the Tripolye greatly increased the likelihood of contracting zoonotic diseases and probably resulted in a substantial parasite burden for the population.

The level of systemic stress documented among the Tripolye from Verteba Cave is higher than that of a Late/Final Neolithic agricultural population from Greece. Papathanasiou (2005) analyzed 436 teeth from Alepotrypa Cave and found $8.3 \%$ of teeth to have at least one enamel hypoplasia. Perhaps the Tripolye experienced more systemic stress than Greek agriculturalists due to their higher population density. It is interesting to note that the level of systemic stress documented in the Greek agriculturalist sample is higher than that of the Ukrainian hunterfisher-gatherers.

The results of our study are in accordance with results obtained by Wittwer-Backofen and Tomo (2008) who found central European agriculturalists to have more enamel hypoplasias than earlier huntergatherers. However, the results of our study differ from those obtained by Bennike and Alexandersen (2007) who found the rates of enamel hypoplasias to immediately decline and then increase following the transition to agriculture in Scandinavia. This suggests that the biological implications of the adoption of agriculture were variable across Europe, and further study is necessary to fully understand the impact of this transition on prehistoric health.

\section{CONCLUSION}

The transition to agriculture was one of the most pivotal events in the biological and cultural evolution of our species. Despite this importance, relatively little is known regarding how the adoption of agriculture affected the health of prehistoric European populations. This study addressed this weakness in the literature by using enamel hypoplasias to document the systemic physiological stress experienced by Tripolye agriculturalists from Ukraine. Comparison of the Tripolye with hunter-fisher-gatherers indicates that the transition to agriculture resulted in increased biological stress in this region. Contextualizing the results archaeologically suggests that the higher prevalence of enamel hypoplasias may have been caused by malnutrition due to reduced dietary breadth and infection resulting from increases in population density, sedentism, and contact with domesticated animals.

\section{ACKNOWLEDGEMENTS}

We would like to thank Alexandr Diachenko, Sean Rafferty, Adam Gordon, and Jackie Nadeau for helpful comments during the preparation of this manuscript, and Alexandr Dudar for his special assistance during excavations. We would also like to thank the students who participated in Grand Valley State University's summer bioarchaeological field schools of 2008 and 2012.

\section{LITERATURE CITED}

Abdel-aal ESM, Hucl P. 2002. Amino acid composition and in vitro protein digestibility of selected ancient wheats and their end products. J Food Comp and Anal 15: 737-747.

Alfonso MP, Standen VG, Castro MV. 2007. The adoption of agriculture among northern Chile populations from the Azapa Valley, 9000-1000BC. In: Cohen MN, Crane-Kramer GMM, editors. Ancient Health: Skeletal Indicators of Agricultural and Economic Intensification. Gainesville: University Press of Florida. p.113-129.

Armelagos GJ. 1990. Health and disease in prehistoric populations in transition. In: Swedlund AC, Armelagos GJ, editors. Disease in Populations in Transition: Anthropological and Epidemiological Perspectives. New York: Bergin and Garvey. p.127-144.

Armelagos GJ, Goodman AH, Jacobs KH. 1991. The origin of agriculture: population growth during a period of declining health. Popul Environ 15: 9-22.

Baynes RD, Bothwell TH. 1990. Iron deficiency. Ann Rev Nutr 10: 133-148.

Bennike P, Alexandersen V. 2007. Population plasticity in southern Scandinavia: from oysters and fish to gruel and meat. In: Cohen MN, Crane-Kramer GMM, editor. Ancient Health: Skeletal Indicators of Agricultural and Economic Intensification. Gainesville: University Press of Florida. p.130-148. 
Buikstra JE, Ubelaker DH. 1994. Standards for data collection from human skeletal remains. Fayetteville: Arkansas Archaeological Survey.

Cassidy CM. 1984. Skeletal evidence for prehistoric subsistence adaptation in the central Ohio River Valley. In: Cohen MN, Armelagos GJ, editors. Paleopathology at the Origins of Agriculture. New York: Academic Press. p.307-345.

Chapman J. 2010. Houses, households, villages, and proto-cities in Southeastern Europe. In: Anthony DW, Chi JY, editors. The Lost World of Old Europe: The Danube Valley, 5000-3500BC. Princeton: Princeton University Press. p.75-89.

Cockburn TA. 1971. Infectious disease in ancient populations. Curr Anthropol 12: 45-62.

Cohen MN, Armelagos GJ. 1984. Paleopathology at the Origins of Agriculture. New York: Academic Press.

Cohen MN, Crane-Kramer GMM. 2007. Ancient Health: Skeletal Indicators of Agricultural and Economic Intensification. Gainesville: University Press of Florida.

Cutress TW, Suckling GW. 1982. The assessment of non-carious defects of enamel. Intl Dent J 32: 117122.

Danforth ME, Jacobi KP, Wrobel GD, Glassman S. 2007. Health and the transition to horticulture in the South-Central United States. In: Cohen MN, Crane-Kramer GMM, editors. Ancient Health: Skeletal Indicators of Agricultural and Economic Intensification. Gainesville: University Press of Florida. p. 65-79.

Ellis L. 1984. The Cucuteni-Tripolye Culture: A Study in Technology and the Origins of Complex Society. Oxford: BAR International Series.

Goodman AH, Allen LH, Hernandez GP, Amador A, Arriola LV, Chavez A, Pelto GH. 1987. Prevalence and age at development of enamel hypoplasias in Mexican children. Am J Phys Anthropol 72: 7-19.

Goodman AH, Lallo J, Armelagos GJ, Rose JC. 1984. Health changes at Dickson Mounds, Illinois (A.D.950-1300). In: Cohen MN, Armelagos GJ, editors. Paleopathology at the Origins of Agriculture. New York: Academic Press. p. 271-305.

Goodman AH, Armelagos GJ, Rose JC. 1980. Enamel hypoplasias as indicators of stress in three prehistoric populations from Illinois. Am J Hum Biol 52: 515-528.

Goodman AH, Rose JC. 1990. The assessment of systemic physiological perturbations from developmental defects of enamel and histological structures. Yrbk PhysAnthropol 3: 59-110.

Goodman AH, Rose JC. 1991. Dental enamel hypoplasias as indicators of nutritional stress. In: Kelley
MA, Larsen CS, editors. Advances in Dental Anthropology. New York: Wiley-Liss. p. 279-294.

Hassett BR. 2012. Evaluating sources of variation in the identification of linear hypoplastic defects of enamel: a new quantified method. J Archaeol Sci 39: 560-565.

Hillson SW. 1996. Dental Anthropology. Cambridge: Cambridge University Press.

Hodges DC. 1987. Health and agricultural intensification in the prehistoric Valley of Oaxaca, Mexico. A J Phys Anthropol 73: 323-332.

Jacobs K. 1993. Human postcranial variation in the Ukrainian Mesolithic-Neolithic. Curr Anthropol 34: 311-324.

Korvin-Piotrovskiy AG. 2008. Trypilian Culture in Ukraine. In: Ciuk K, editor. Mysteries of Ancient Ukraine. Toronto: Royal Ontario Museum. p. 22-31.

Korvin-Piotrovskiy AG. 2012. Tripolye culture in Ukraine. In: Menotti F, Korvin-Piotrovskiy AG, editors. The Tripolye Culture Giant- Settlements in Ukraine: Formation, Development, and Decline. Oxford: Oxbow Books. p. 6-18.

Korvin-Piotrovskiy AG, Chabanyuk V, Shatilo L. 2012. Tripolian house construction: conceptions and experiments. In: Menotti F, Korvin-Piotrovskiy AG, editors. The Tripolye Culture GiantSettlements in Ukraine: Formation, Development, and Decline. Oxford: Oxbow Books. p. 210-229.

Kruts VA. 1989. Kistorrii naseleniya tripolskoi kultury v mezhdurechye Yuzhnogo Buga I Dnepra. In: Pervobytnaya Arkheologia, Berezanskaya SS, editors. Kiev: Naukova Dumka. p. 117-132.

Kruts VA. 2012. Giant-settlements of Tripolye culture. In: Menotti F, Korvin-Piotrovskiy AG, editors. Tripolye Culture Giant-Settlements in Ukraine: Formation, Development, and Decline. Oxford: Oxbow Books. p. 70-78.

Larsen CS. 1995. Biological changes in human populations with agriculture. Ann Rev Anthropol 24: 185213.

Larsen CS. 1997. Bioarchaeology: Interpreting Behavior from the Human Skeleton. Cambridge: Cambridge University Press.

Larsen CS. 2006. The agricultural revolution as environmental catastrophe: implications for health and lifestyle in the Holocene. Quat Int 150: 12-20.

Lillie MC. 1996. Mesolithic and Neolithic populations in Ukraine: indications of diet from dental pathology. Curr Anthropol 37: 135-142.

Lillie MC. 2008. The Trypilian culture in context. In: Ciuk K, editor. Mysteries of Ancient Ukraine: The Remarkable Trypilian Culture. Toronto: Royal Ontario Museum. p. 11-16. 
Lillie MC, Budd C. 2011. The Mesolithic-Neolithic transition in Eastern Europe: integrating stable isotope studies of diet with paleopathology to identify subsistence strategies and economy. In: Pinhasi R, Stock JT, editors. Human Bioarchaeology of the Transition to Agriculture. Chichester: John Wiley and Sons. p. 43-62.

Lillie MC, Budd C, Potekhina I. 2011. Stable isotope analysis of prehistoric populations from the cemeteries of the Middle and Lower Dnieper Basin, Ukraine. J Archaeol Sci 38: 57-68.

Lillie MC, Jacobs K. 2006. Stable isotope analysis of 14 individuals from the Mesolithic cemetery of Vasilyevka II, Dnieper Rapids region, Ukraine. J Archaeol Sci 33: 880-886.

Lillie MC, Richards M. 2000. Stable isotope analysis and dental evidence of diet at the MesolithicNeolithic transition in Ukraine. J Archaeol Sci 27: 965-972.

Lovejoy CO. 1985. Dental wear in the Libben population: its functional pattern and role in the determination of adult skeletal age at death. Am J Phys Anthropol 68: 47- 56.

Lukacs JR. 1989. Dental paleopathology: methods for reconstructing dietary patterns. In: Iscan MY, Kennedy KAR, editors. Reconstruction of Life from the Skeleton. New York: Alan R. Liss. p. 261-286.

Lukacs JR. 1992. Dental paleopathology and agricultural intensification in South Asia: new evidence from Bronze Age Harappa. Am J Phys Anthropol 87: 133-150.

Lukacs JR, Nelson GC, Walimbe SR. 2001. Enamel hypoplasias and childhood stress in prehistory: new data from India and Southwest Asia. J Archaeol Sci 28: 1159-1169.

Markevich VI. 1981. Pozdnetripolskiye plemena Severnoi Moldavii . Kishinev: Shtiintsa.

Markova OV. 2008. Archaeozoological research on the Trypilian culture. In: Ciuk K, editor. Mysteries of Ancient Ukraine: The Remarkable Trypilian Culture. Toronto: Royal Ontario Museum. p. 79- 80.

Marinescu-Bâlcu S. 1981. Tîrpesti, from prehistory to history in eastern Romania. Oxford: British Archaeological Reports.

Marquez-Morfin L, Storey R. 2007. From early village to regional center in Mesoamerica: an investigation of lifestyle and health. In: Cohen MN, CraneKramer GMM, editors. Ancient Health: Skeletal Indicators of Agricultural and Economic Intensification. Gainesville: University Press of Florida. p. 80-91.

Meiklejohn C, Zvelebil M. 1991. Health status of European populations at the agricultural transition and the implications for the adoption of farming. In: Bush $\mathrm{H}$, Zvelebil M, editors. Health in Past Societies: Biocultural Interpretation of Human Skeletal Remains in Archaeological Contexts. Oxford: Tempus Repartum. p. 129-144.

Meindl RS, Lovejoy CO. 1985. Ectocranial suture closure: a revised method for the determination of skeletal age at death based on the lateral-anterior sutures. Am J Phys Anthropol 68: 57-66.

Milisauskas S. 2011. Early Neolithic, the first farmers in Europe, 7000-5500/5000BC. In: Milisauskas S, editor. European Prehistory: a Survey. New York: Springer. p. 153-222.

Nikitin AG, Sokhatsky MP, Kovaliukh MM, Videiko MY. 2010. Comprehensive site chronology and ancient mitochondrial DNA analysis from Verteba Cave- a Trypillian culture site of Eneolithic Ukraine. Interdisciplinaria Archaeologica 1: 9-18.

Papathanasiou A. 2005. Health status of the Neolithic population of Alepotrypa Cave, Greece. Am J Phys Anthropol 126: 377-390.

Papathanasiou A, Larsen CS, Norr L. 2000. Bioarchaeological inferences from a Neolithic ossuary from Alepotrypa Cave, Diros, Greece. Intl J Osteoarchaeol 10: 210-228.

Pashkevych HO. 2008. Paleobotanical research into the Trypilian culture. In: Ciuk K, editor. Mysteries of Ancient Ukraine: The Remarkable Trypilian Culture. Toronto: Royal Ontario Museum. p. 75-78.

Pashkevych HO. 2004. Gathering and usage of vegetable resources. In: Videiko M, editor. Encyclopedia of the Tripolian Civilization. Kiev: Ukrpoligraphmedia. p. 149-150.

Passek TS. 1961. Rannezemledelcheskiye (tripolskiye) plemena Podnestrovya. Materialy I issledovaniya po arkheologii SSR 84. Moscow: Nauka.

Pechenkina EA, Benfer RA, Zhijun W. 2002. Diet and health changes at the end of the Chinese Neolithic: the Yangshao/Longshan transition in Shaanxi Province. Am J Phys Anthropol 117: 15-36.

Perzigian AJ, Tench PA, Braun DJ. 1984. Prehistoric health in the Ohio River Valley. In: Cohen MN, Armelagos GJ, editors. Paleopathology at the Origins of Agriculture. New York: Academic Press. p. 347366.

Rassamakin Y. 2012. Absolute chronology of Ukrainian Tripolye settlements. In: Menotti F, KorvinPiotrovskiy AG, editors. The Tripolye Culture Giant-Settlements in Ukraine: Formation, Development, and Decline. Oxford: Oxbow Books. p. 19-69. Ryzhov SN. 2012. Relative chronology of the giantsettlement period BII-CI. In: Menotti F, KorvinPiotrovskiy AG, editors. The Tripolye Culture Gi- 
ant-Settlements in Ukraine: Formation, Development, and Decline. Oxford: Oxbow Books. p. 79115.

Skinner HF, Dupras TL, Maya-Sola S. 1995. Periodicity of linear enamel hypoplasia among Miocene Dryopithecus from Spain. J Paleopathol 7: 195-222.

Starling AP, Stock JT. 2007. Dental indicators of health and stress in early Egyptian and Nubian agriculturalists: a difficult transition and gradual recovery. Am J Phys Anthropol 134: 520-528.

Temple DH. 2010. Patterns of systemic stress during the agricultural transition in prehistoric Japan. Am J Phys Anthropol 142: 112-124.

Videiko MY. 2004. Encyclopedia of Trypiliian Civilization. Kiev: Ukrpoligraphmedia.

Walker PL. 1986. Porotic hyperostosis in a marinedependent California Indian population. Am J Phys Anthropol 69: 345-354.

Walker PL. 2008. Sexing skulls using discriminant function analysis of visually assessed traits. Am J Phys Anthropol 136: 39-50.

Walker PL, Bathurst RR, Richman R, Gjerdrum T, Andrushko A. 2009. The causes of porotic hyperostosis and cribra orbitalia: a reappraisal of the irondeficiency anemia hypothesis. Am J Phys Anthropol 139: 109-125.

Winter GB, Brook AB. 1975. Enamel hypoplasias and anomalies of the enamel. Dent Clin North Am 19: 3 24.

Wittwer-Backofen U, Tomo N. 2008. From health to civilization stress? In search of a health transition during the early Neolithic in Europe. In: BocquetAppel JP, Bar-Yosef O, editors. The Neolithic Demographic Transition and its Consequences. New York: Springer. p. 501-538.

Zbenovich VG. 1996. The Tripolye culture: centenary of research. J World Prehist 10: 199-241.

Zhuralev OG. 2008. Stock-Breeding and Hunting of the Trypolian Tribes of the Territory of Ukraine. Kyiv: Shliakh.

Zvelebil M, Dolukhanov P. 1991. The transition to farming in eastern and northern Europe. J World Prehist 5: 233-278.

Zvelebil M, Lillie M. 2000. Transition to agriculture in eastern Europe. In: Price TD, editors. Europe's First Farmers. Cambridge: Cambridge University Press. p. 57-92. 